\title{
Celebration/Subversion of French Assimilation: A Contrapuntal Analysis of Zebda's Art
}

\author{
Fella Benabed \\ Badji Mokhtar - Annaba University, Algeria. Email: benabed.fella@gmail.com \\ Received October 11, 2017; Revised November 18, 2017; Accepted November 30, 2017; Published December 09, 2017.
}

\begin{abstract}
This article attempts to understand the ambivalent attitude of celebration/subversion towards French immigration and assimilation policies by artists of immigrant descent. Using Edward Said's concept of contrapuntal reading, it analyzes the song "J'y suis j'y reste" by Zebda, a music band whose protest songs are a form of militant struggle against discrimination. Such artists, who celebrate the varied cultural landscape and the polyphonic identity of the contemporary French Republic, aspire for a shift from a monocultural melting pot to a multicultural mosaic that honors its values of liberty, equality, and fraternity.
\end{abstract}

Keywords: immigration, assimilation, celebration, subversion, contrapuntal reading, hybridity

\section{Introduction}

In France, musicians of immigrant origins have gained momentum in the 1980 and 1990 with their vibrant glocal music, a cross-pollination of global and local tunes that expresses their polyphonic identities and counters the mainstream hegemonic discourse about minorities. That period in France, as in many European countries, witnessed the beginning of heated debates on the "colonial boomerang"1 through questions of immigration, identity, and racism. This article relies on Edward Said's concept of contrapuntal reading to understand Zebda's song "J'y suis j'y reste" and to reflect on the status of immigrants in the French cultural landscape. It analyzes the issue from a postcolonial ${ }^{2}$ lens, which is pertinent to the immigrants' condition in France because they seem to be integrated to the extent they whitewash themselves of their origins and perfectly fit the mold of French culture.

\section{The French immigration malaise}

The origins of the French immigration malaise can arguably be traced to its colonial history and the failure of its immigration policy. French Republicanism is constructed on the idea that the country is "one and indivisible" and that "communautarisme" 3 is a danger to national unity (Lebrun, 2009, p. 66). The Beurs, second-generation immigrants of North African descent, are the most visible minority in France, and they probably suffer from the worst discrimination. As their parents mostly migrated in the 1960s, they came to maturity in the 1980 os and started a "Beur movement", with a blossoming in political and cultural expression. In 1983, they organized the Beurs' March, also called the March for Equality and Against Racism.

(c) AesthetixMS 2016. This Open Access article is published under a Creative Commons Attribution Non-Commercial 4.0 International License (http://creativecommons.org/licenses/by-nc/4.o/), which permits non-commercial re-use, distribution, and reproduction in any medium, provided the original work is properly cited. For citation use the DOI. For commercial re-use, please contact editor@rupkatha.com. 
Despite their attempt to prove they are full French citizens by virtue of birth and education, immigrants - mainly of African origins - do not feel well integrated in the French society. Youth riots have hence broken out at different times and scopes in some French cities like Lyon (1991/1996), Toulouse (1998), and Paris (1997/2000/2005). They express the rage felt by young people of immigrant descent, living in ghetto-like suburban areas, where school failure and unemployment are rampant, racial discrimination and police molestation prevalent. The 2005 suburban protests, regarded as the greatest civil unrest in the country's recent history, followed the death of two youngsters of African descent in the Parisian suburb of Clichy-sous-Bois; it then spread to other poverty-stricken suburbs across France. On October 30, 1995, the police shot a tear gas grenade in the Clichy-sous-Bois mosque because of a suspected car parked in front of it. The "zero tolerance" of the government and the biased comments of some politicians fueled violence, particularly the words of Nicolas Sarkozy, then Minister of the Interior, who qualified rioters as "racaille" (scum). To restore order, the government imposed the state of emergency as it did in 1955 during the Algerian War. As violence reached neighboring countries like Belgium, Germany, and Italy, European analysts expressed their apprehension that the movement would touch their cities, especially those with elevated rates of immigrant populations. These protests hence served as a warning shot not only for France, but also for other European countries to revise their ways of coping with immigrant minorities.

French suburban riots obliged analysts to think about its underlying causes. Their frequency reflects the rigidness and failure of the country's immigration policy, with its promotion of a monocultural melting pot rather than a multicultural mosaic. Leonard Berkowitz's "frustration-aggression hypothesis" is often used to explain the psychological motives of social unrest, i.e., human beings who have thwarted aspirations react violently towards the source. Ted Gurr's "relative economic deprivation theory" also provides an interesting explanation; in his view, riots originate from the "actors' perception of discrepancy between their value expectations and their value capabilities" (1970, p. 24). In the French suburban context, immigrants feel a great discordance between what they actually have and what they think they deserve. According to analysts, the suburban outburst was predictable because African immigrants constitute a large portion of the French population, but they are not treated like full-blood French citizens or immigrants of European origins. The families and friends of victims believe that young people from "visible minorities" escape because they apprehend the policemen's treatment. They complain for having frequent and disrespectful identity checks, for being held in custody and beaten in police stations, sometimes for no valid reasons. As a matter of fact, "la Commission Nationale de Déontologie de la Sécurité" (the French National Commission of Security Deontology) revealed that French police violence increased by $38 \%$ in 2004 (just before the 2005 riots), especially on racist grounds.

The feelings that a member is unfairly or violently treated often fuels the protest of the whole community. For Daniel Lapeyronnie, "the death of young people during police interventions always creates a strong individual and collective emotion that crystallizes the feeling of a 'we', victim of injustice, opposed to a 'they' of a sinful police". Individuals are hence moved into action by an "emotional energy" related to their "attachment to life or respect" (2006, p. 439, my translation). In "The Pyres of Autumn", Jean Baudrillard also criticizes France for its exclusionary policies saying:

It is a short step from disaffiliation to desafío-defiance. All the excluded, the disaffiliated, whether from the banlieues, immigrants or 'native-born', at one point or another turn 
their disaffiliation into defiance and go onto the offensive. It is their only way to stop being humiliated, discarded or taken in hand. (2006, p. 7)

Baudrillard therefore believes that the events of the banlieues are symptoms of malaise in a society that is at odds with itself.

Analysts also blame hip-hop artists for inciting suburban youth to riot because groups like Alliance Ethnik, NTM, and Zebda, have been writing songs that decry the lifestyle of French suburban populations by raising issues like substandard housing, joblessness, and discrimination. In Dayna Oscherwitz's view, hip-hop is the major medium for "urban youth to articulate their vision of the world, to describe the social and material realities of the banlieue" (2004, p. 43). French hip-hop artists do not probably incite rebellion, but mainly reflect on the causes that lead youngsters in the suburbs to act in that manner.

\section{A Contrapuntal Reading of Zebda's Festive Struggle}

In Culture and Imperialism (1993), Edward Said uses the concept of contrapuntal reading to understand literary texts, but it can also be used to understand songs as the author, also a pianist, borrows the term "counterpoint" from music [a musical composition of two or more melodies]. Contrapuntal reading examines hegemonic culture in relation to its counterhegemonic counterpart. It needs an "awareness both of the metropolitan history that is narrated and of those other histories against which (and together with which) the dominating discourse acts" (Said, 1993, p. 51). A contrapuntal reading of a text, as a song in this article, needs to situate it in the world where it is created, which Said calls the "worldliness" of the text. For Geeta Chowdhry, the "goal of a contrapuntal reading is thus to not privilege any particular narrative but reveal the 'wholeness' of the text, the intermeshed, overlapping, and mutually embedded histories of metropolitan and colonized societies and of the elite and subaltern" (2007, p. 105). Contrapuntal reading hence regards both the perspectives of imperialism and the resistance to it.

Despite the prejudice that hip-hop is a vehicle of suburban violence, Zebda singles out with a unique combination of cheerful tunes and witty messages. The name is the Arab translation of the term "beurre" (the French word for "butter"); it is the homophone of "Beur", which means "Arab" in Verlan (a French slang that consists in reversing syllables). The band is composed of three singers, children of Algerian immigrants, and four musicians of French, Italian, and Spanish origins. The members' diverse ethnic origins reflect the contemporary cultural landscape of France, and from a postcolonial lens, their protest songs, characterized by glocal tunes and lyrics, reflect a counter-hegemonic discourse, a form of militant struggle against discrimination. Zebda particularly describe the way "banlieue" youth enter the vicious circle of drug, violence and crime; they condemn racism and exclusion, and claim respect for all. Zebda also voice the immigrants' hope for a real integration with respect for cultural diversity. Magyd Cherfi, one of the singers, maintains, "people hear our music and recognize the different influences as things they've grown up with and are used to. That indicates that these influences, which may have once been considered foreign, are now a part of the French cultural fabric" (qtd. in Crumley, 1999). He further believes that people are getting increasingly conscious of that, with an attitude of celebration rather than apprehension.

According to Cherfi, his band's aimis to provoke a "militant emotion" by mixing "the blackness of the letter with the lightness of music" to touch both "intelligence and feeling" (Cherfi \& Monin, 2004, p. 119, my translation). Cherfi confesses that when he was a teenager, he was ashamed of belonging to a poor immigrant family. He proudly claims that going to French schools 
gave him role models to follow as well as a refined use of the French language (In Marx-Scouras, 2005, p. 116). In his festive protest songs, Cherfi expresses his elevated intellectual capital by referring to famous French writers like Victor Hugo and Voltaire, as well as singers like Georges Brassens and Claude Nougaro. Hence, "intellectual sophistication" (Lebrun, 2009, p. 82) and militant struggle are reasons behind Zebda's important position in the French cultural landscape.

Zebda came into the limelight after Jacques Chirac's speech on "le bruit et l'odeur" (the noise and the smell). When he was the Mayor of Paris in 1991, he complained about the "overdose" of foreigners in his country; what follows is an excerpt from his speech:

Comment voulez-vous que le travailleur français qui travaille avec sa femme et qui ensemble gagnent environ 15000 FF et qui voit sur le palier à côté de son HLM entassée, une famille avec un père de famille, trois ou quatre épouses, et une vingtaine de gosses, et qui gagne 50000 FF de prestations sociales sans naturellement travailler. Si vous ajoutez à cela le bruit et l'odeur, eh bien le travailleur français sur le palier, il devient fou. Et ce n'est pas être raciste que de dire cela. (qtd in Zebda, 1995)

How would you like the French worker who, with his wife, gains about $15000 \mathrm{FF}$, and who sees on the same floor, a family crammed with a father, three or four wives, and about twenty children, and who gains $50000 \mathrm{FF}$ of social benefits, naturally without working. If you add to this the noise and the smell, well, the French worker goes mad. And it isn't racist to say that. [my translation]

This speech contrasts with the attitude towards immigrants of European origins because these ones allegedly create fewer problems than those of African origins. The underlying cause, however, can be that these immigrants do not receive the same sort of treatment by the authorities and are also more easily assimilated in French society owing to similar cultural backgrounds.

One of Zebda's most popular songs is "J'y suis j'y reste" (I'm here to stay), from Utopie d'occase album (2002). The lyrics highlight some of the major issues that often provoke suburban protests. A guitar and an accordion open the song in a slow nostalgic tempo, as the singers describe their town Toulouse and denounce the exclusion of immigrants. The song starts with the following words: "Ma ville a ses petits avions / Jolis comme des papillons / Mais qui les prend à votre avis" (My town has its small planes / Nice like butterflies / But who takes them in your view [my translation]). The reference to the airplanes made in Toulouse can stand for the deportation of immigrants because the title of the song, "J'y suis j'y reste", is probably inspired from a hunger protest against immigrants' deportation in the 1980s (Ervine, 2008, pp. 203-204). When the singers describe suburban inhabitants from Senegal, Malta or Algeria, the use of instruments like a West African drum and a North African flute reflects their multiethnic origins. However, when the singers compare their own feelings of being born in France to their elders' nostalgia for their native country, they rhythmically reiterate in chorus: "Ils pleurent mais moi je reste / Et je le dis sans conteste / J'y suis j'y reste" (They cry but I stay / And I say it decidedly / I'm here to stay [my translation]). The insistence of the tone reflects their strong attachment to France, the country of their birth and upbringing. While first generation immigrants feel nostalgia for their homeland, their children consider France as their homeland.

The next part of the song depicts the discrimination against "banlieue" residents: "Ils ont l'accent mais ils n'ont pas l'accès / Tout ça, ça vous fait de méchantes poussées" (They have the accent but no access / All that gives foul upsurges [my translation]). The singers show the injustice against immigrants who speak like French people, but who have no equal access to 
French rights. The following is another interesting passage from the song: "Comme une guerre qui porte son nom / A chaque prénom" (Like a war that bears its name / with each first name [my translation]). This allusion to the Algerian War (called "the war without name") reflects the lingering legacy of French colonialism (Ervine, 2008, p. 206). The song's serious theme notwithstanding, it ends in festive Kabylian ${ }^{4}$ music, the ancestral heritage of the singers.

Jonathan Ervine remarks that Zebda's multicultural aspiration is represented in the cover of the album La Tawa (2003), the French transcription of an Arabic noun that means a "large cooking pot". The picture is an Arabic calligraphy in the form of a Gallic rooster, a French national emblem; below the picture is the translation "L'Humanité ... ma famille / Le Monde ... ma patrie" (Humanity ... my family / The world ... my homeland [my translation] $)^{5}$. This album cover, therefore, summarizes Zebda's philosophy, whose music is a mixture of genres (gnawa, raï, kabylian, musette, salsa, reggae, etc.). In The Location of Culture (1994), Homi K. Bhabha warns against the perils of "fixity and fetishism" in identities (p. 9), and shows that hybridity is "the warlike sign of the native", because it seeks "to change the often coercive reality" of the postcolonial situation (p. 104). Musical hybridity in the song of

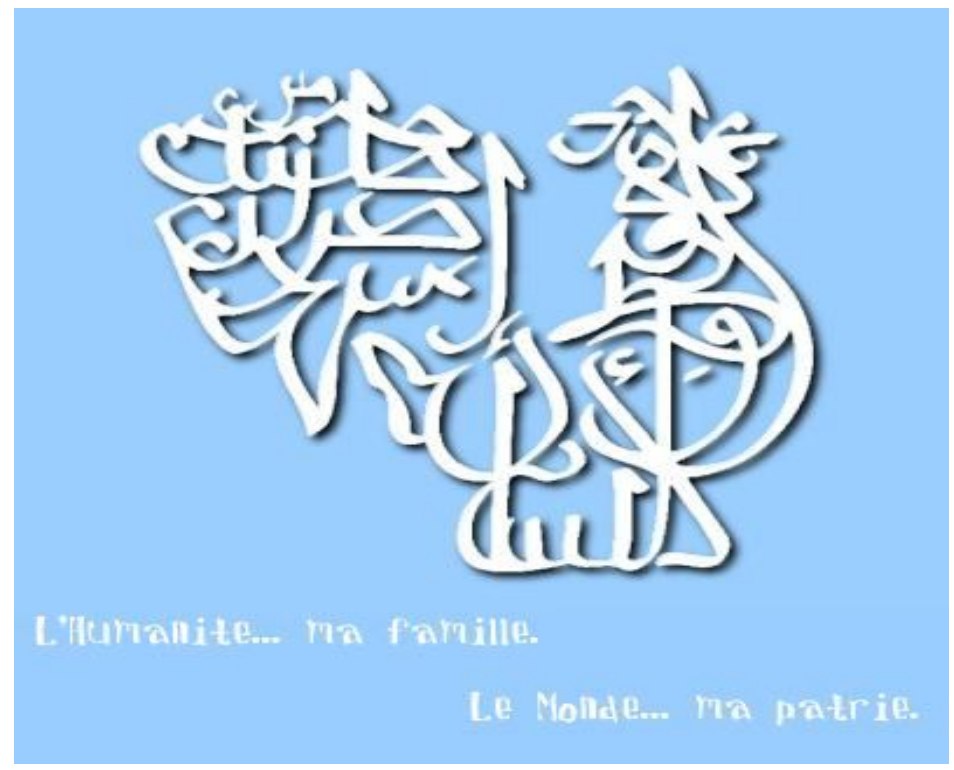
Zebda hence "turns the discursive conditions of dominance into grounds of intervention" (p. 175); it equally denounces the danger of French rigid conceptions of identity.

Because of its success among young people, Zebda created the association Vitécri, later renamed Tactikollectif, which formed a list of independent candidates called Les motivé-e-s (The Motivated) in the 2001 local elections, and obtained $12.49 \%$ of the voices. During the electoral campaign, the Toulouse local TV would not call them Les motivé-e-s, but designate them by the name of Salah Amokrane, the head of the list and one of Zebda's singers, probably to encourage slogans like "Pas d'Arabes au Capitole" (No Arabs in the Capitol, Toulouse's City Hall Council) (Leroux, 2005). Their song, "Motivés" (Motivated) states the aim of the movement: "C'est nous qui brisons les barreaux des prisons pour nos frères / La haine à nos trousses et la faim qui nous pousse, la misère" (We are the ones who break prison bars for our brothers / Hatred on our heels and hunger that thrusts us, misery [my translation]). In February 2017, Zebda returned to the musical scene, henceforward called Les motivés, with its 1997 album Chants de lutte (Fighting songs) with a subtitle "Y'a toujours pas d'arrangement!" (There is still no arrangement [my translation]), and their struggle continues...

\section{Conclusion}

Zebda's art provides an alternative worldview where "musical arrangements represent cultures and identities coexisting and combining" (Oscherwitz, 2004, p. 47). This is probably the reason why World Music attracts young people of different origins, even from the mainstream culture. Oscherwitz reports a 2002 poll done by SOFRES (Société Française d'Etudes par Sondages), in 
which the fans of hybrid music have by half less racist attitudes than older age groups (2004, p. 48). The continuing success of this trend is a presage that, as Hugues Bazin optimistically notes in his reference to hip-hop, if France is not yet a multicultural country, music presages it will become (1995, p. 111). Jennifer Yee nevertheless believes that "the enthusiastic mixophilia" is a "false promise" for those who dream about the end of interracial conflicts (qtd in Lebrun, 2009, p. 73).

By a "contrapuntal reading" of Zebda's "J'y suis j'y reste," this article focused on the worldliness of the lyrics to understand the historical and socio-political issues that have influenced their writing. In this song, contemporary French identities are not monophonic but polyphonic; they are characterized not only by subversion, but also by celebration. In Zebda's festive celebration/subversion, eclecticism does not appear only in the texts but also in the music; it reflects the dream of a French society that assumes its pluralism and abides by it Republican values of liberty, equality, and fraternity.

\section{Endnotes}

${ }^{1}$ The phrase is borrowed from John Milfull's title "Decolonising Europe? The colonial boomerang" (2008). Australian Journal of Politics $\mathcal{E}$ History. 54-3, 464-470.

${ }^{2}$ Postcolonialism covers different kinds of experiences like "migration, slavery, suppression, resistance, representation, difference, race, gender, place, and responses to the influential master discourses of imperial Europe" (Ashcroft et al., 1989, p. 2).

3 "Communitarisme," as a doctrine, stipulates that individuals do not exist independently of their ethnic or religious belongings (Lacroix, 2007).

${ }^{4}$ Kabylian is an adjective related to Kabylie, a region in the North of Algeria, inhabited by the Amazigh indigenous group.

${ }^{5}$ This is probably a reference to Khalil Gibran's saying: "La terre est ma patrie et l'humanité ma famille" (The universe is my country and the human family is my tribe (6)[My translation]).

\section{References}

Ashcroft, B., Griffiths, G. \& Tiffin, H. (1989). The Empire Writes Back: Theory and Practice in Post-Colonial Literatures. London \& New York: Routledge.

Baudrillard, J. (2006). “The Pyres of Autumn.” New Left Review. 37, 5-7.

Bazin, H. (1995). La culture hip-hop. Paris: Desclée de Brouwer.

Bhabha, H.K. (1994). The Location of Culture. London \& New York: Routledge.

Cherfi M. \& Monin, P.Y. (2004). "L'émotion militante." Cités. 3.19, 117-120.

Chowdhry, G. (2007). "Edward Said and Contrapuntal Reading: Implications for Critical Interventions in International Relations." Millenium: Journal of International Studies. 36 (1), 101-16.

"Commission nationale de déontologie de la sécurité: Rapport 2004." 26 Sep. 2005. Retrieved from http://www.libertysecurity.org/article410.html

Crumley, B. (1999). "Zebda: The Sound of the New France." CultureKiosque. Retrieved from http://www.culturekiosque.com/nouveau/portrait/rhezebda.html

Ervine, J. (2008). "Citizenship and Belonging in Suburban France: The Music of Zebda." ACME: An International E-Journal for Critical Geographies. 7.2, 199-213.

Gibran, Khalil. "Poet's Voice XV." Classic Poetry Series. Retrieved from

http://www.poemhunter.com/i/ebooks/pdf/khalil_gibran_2004_9.pdf

Gurr, T. (1970) Why Men Rebel. Princeton: Princeton University Press.

Lacroix, J. (2007). “Communautarisme et pluralisme dans le débat français : essai d'élucidation.” Éthique publique 9.1. Retrieved from http://ethiquepublique.revues.org/1786 
Lapeyronnie, D. (2006). "Révolte primitive dans les banlieues françaises. Essai sur les émeutes de l'automne 2005.” Déviance et Société. 4.30, 431-448.

Lebrun, B. (2009). Protest Music in France: Production, Identity and Audiences. Surrey \& Burlington: Ashgate.

Leroux, B. (2005). "Une campagne électorale spectaculaire: Les 'motivé-e-s' en représentation." Interrogations? Revue pluridisciplinaire des sciences de l'homme et de la société. $\mathrm{N}^{\circ} 1$. Retrieved from http://www.revue-interrogations.org/article.php?article=22

Marx-Scouras, D. (2005). La France de Zebda, Paris, Autrement.

Oscherwitz, D.L. (2004). "Pop Goes the Banlieue: Musical Métissage and the Articulation of a Multiculturalist Vision." Contemporary French and Francophone Cultural Studies. 8.1, 43-50.

Perrier, F. (2007). "La France, dans sa diversité, est un acquis irréversible." L'humanité. Retrieved from http://www.humanite.fr/2007-06-22_Cultures_-La-France-dans-sa-diversite-est-un-acquis-irreversible Said, E.W. (1993). Culture and imperialism. New York: Vintage Books.

Zebda. (1995). "Le bruit et l'odeur." Album Le bruit et l'odeur. Paris: Barkley.

---. (1997). "Motivés." Album Motivés. Paris: Barkley.

---. (2002). "J'y suis j'y reste." Album Utopie d'occase. Paris: Barkley.

Fella Benabed is an associate professor at Annaba University (Algeria). She has a Doctorate in comparative literature from Annaba University as well as a certificate in Contemporary American Literature from the University of Louisville, Kentucky (USA). In her research, she is interested in the postcolonial, narrative, and ecological approaches to New Literatures in English and French. 